\author{
Северин Віктор Дмитрович \\ кандидат мистецтвознавства, доцент, \\ доцент кафедри «Дизайн середовища» \\ Харківської державної академії \\ дизайну і мистецтв \\ ORCID 0000-0003-0049-0815 \\ severiny84@gmail.com \\ Северин Надія Василівна \\ кандидат філософських наук, доцент, \\ доцент кафедри гуманітарних наук \\ Національного технічного університету \\ «Харківський політехнічний інститут» \\ ORCID 0000-0002-4802-1738 \\ severiny84@gmail.com \\ Проценко Ольга Петрівна \\ доктор фрілософських наук, професор, \\ професор кафедри соціально-гуманітарних \\ дисциплін Харківського національного \\ університету будівництва та архітектури \\ ORCID 0000-0002-4639-8961
}

\title{
ДИЗАЙН ВИСТАВКОВИХ ЕКСПОЗИЦІЙ У СУЧАСНІЙ ПРОЕКТНО-ХУДОЖНІЙ ДІЯЛЬНОСТІ
}

Мета роботи. Дослідження пов'язане з визначенням основних складових виставкового дизайну та новітніх технологій, які використовуються у організації виставкових просторів. Метою даної роботи $€$ з'ясування ролі дизайну виставкових експозицій у проектно-художній діяльності. Методологія. Для дослідження концепту «виставковий дизайн» було використано загальнонаукові методи: аналіз і синтез, індукцію і дедукцію, опис. Метод системно-функціонального аналізу допоміг дослідити дане явище у взаємозв'язку з іншими галузями дизайну: архітектурою, дизайном інтер'єрів, графічним дизайном, середовищним дизайном. Міждисциплінарний та компаративний підходи спонукали до об'єднання різних концепцій для визначення місця виставкового дизайну в інфрормаційно-комунікативному просторі сучасного суспільства. Провідними для дослідження виставкового дизайну стали герменевтичний та френоменологічний методи. Наукова новизна. Вперше здійснено ґрунтовне дослідження концепту «виставковий дизайн» та з'ясовано його роль і функції у сучасному суспільстві. Наведені приклади показують, що виставкова експозиція візуалізує і демонструє економічні та культурні досягнення однієї чи кількох країн. Висновки. Реалізація міждисциплінарного підходу до створення проекту виставки дає можливість передавати інформацію на декількох рівнях. Виставковий дизайн є синтезом усіх видів дизайну - архітектурного, середовищного, промислового, ландшафтного, графічного. Завдяки дизайну виставка інтегрується у дизайн інтер'єрів та архітектуру оточуючого середовища, стає способом просування товарів народного споживання і художніх творів.

Ключові слова: експозиція, виставковий дизайн, предметно-просторове середовище, культуркомунікативний простір.

Северин Виктор Дмитриевич, кандидат искусствоведения, доцент кафредры «Дизайн среды» Харьковской государственной академии дизайна и искусств; Северин Надежда Васильевна, кандидат фрилософрских наук, доцент, доцент кафедры гуманитарных наук Национального технического университета "Харьковский политехнический институт»; Проценко Ольга Петровна, доктор фрилософрских наук, профрессор, профрессор кафедры социально-гуманитарных дисциплин Харьковского национального университета строительства и архитектуры

Дизайн выставочных экспозиций в современной проектно-художественной деятельности

Цель работы. Исследование связано с изучением основных составляющих выставочного дизайна и инновационных технологий, которые используются в организации выставочных пространств. Цель данной работы определение роли дизайна выставочных экспозиций в современной проектно-художественной деятельности. Методология. Для исследования концепта «выставочный дизайн» было использовано общенаучные методы: анализ и синтез, индукцию и дедукцию, описание. Метод системно-функционального анализа помог исследовать данное явление в его взаимосвязи с другими отраслями дизайна: архитектурой, дизайном интерьеров, графическим дизайном, средовым дизайном. Междисциплинарный и компаративный подходы побудили к объединению разных концепций для выявления места выставочного дизайна в информационно-коммуникативном пространстве современного общества. Ведущими для исследования выставочного дизайна стали герменевтический и феноменологический методы. Научная новизна работы состоит в обстоятельном исследовании концепта «выставочный дизайн», выяснении его роли и функций в современном обществе. Приведённые примеры показывают, что выставочная экспозиция визуализирует и демонстрирует экономические и культурные достижения одной или нескольких стран. Выводы. Реализация междисциплинарного подхода к созданию проекта выставки дает возможность передавать информацию на нескольких уровнях. Выставочный дизайн соединяет все виды дизайна

() Северин В. Д., 2020

(С) Северин Н. В., 2020

(c) Проценко О. П., 2020 
- архитектурный, средовой, промышленный, ландшафтный, графический. Благодаря дизайну выставка интегрируется в дизайн интерьеров и архитектуру окружающей среды, становится способом продвижения товаров народного потребления и художественных произведений.

Ключевые слова: экспозиция, выставочный дизайн, предметно-пространственная среда, культуркоммуникативное пространство.

Severyn Viktor, Ph.D. of Art history, Associate Professor of Kharkiv State Academy of Design and Arts; Severyn Nadiia, Ph.D. in Philosophy, Associate Professor, Associate Professor of the Chair of Humanities of National Technical University "Kharkiv Polytechnic Institute", Protsenko Olga, Doctor of Philosophical Sciences, Professor, Professor of Kharkiv National University of Civil Engineering and Architecture

\section{Design of exhibition expositions in modern design and art activities}

Purpose of Article. The research is related to the study of the main components of the exhibition design and innovative technologies that are used in the organization of exhibition spaces. The purpose of this work is to determine the role of the design of exhibits in modern design and artistic activities. Methodology. Common scientific methods, namely analysis, and synthesis, induction and deduction, description, are used to study the exhibition design. The method of system-functional analysis helped to investigate this phenomenon in interconnection with other areas of design: architecture, interior design, graphic design, and environmental design. Interdisciplinary and comparative approaches have led to the unification of various concepts to identify the role of exhibition design in modern information and communicative space, namely art studies and aesthetics, social philosophy, and semiotics. Hermeneutical and phenomenological methods are basic for the research of exhibition design. Interdisciplinary and comparative approaches have led to the integration of different concepts to determine the place of exhibition design in the informational and communicative space of modern society. Hermeneutical and phenomenological methods became the leading examples of the exhibition design. The scientific novelty of the work consists of thorough research of the concept of "exhibition design" and clarification of its role and functions in modern society. The examples presented show that the exhibition exposition visualizes and demonstrates the economic and cultural achievements of one or more countries. Conclusions. The implementation of the interdisciplinary approach to the design of the exhibition gives the opportunity to transmit information at several levels. Exhibition design is a synthesis of all kinds of design - architectural, environmental, industrial, landscape, graphic. Thanks to the design, the exhibition integrates into the design of interiors and the architecture of the environment, and it becomes a way of promoting consumer goods and artistic works.

Key words: exhibition, exhibition design, object-spatial environment, cultural and communicative space, information and communicative sphere.

У сучасних умовах інтеграції України у світовий культурний простір та розвитку національної культури виставкова діяльність стає важливим способом просування товарів, послуг та культурних досягнень країни на вітчизняний і світовий ринок. Виставка як самостійний феномен проектнохудожньої культури завжди пов'язана з матеріальними та духовними надбаннями людства, політичними, економічними, соціальними і науково-технічними напрямками його практичної діяльності. Вона виконує важливу роль - демонстрування накопичених досягненнь у різних соціально-культурних сферах. Сучасний виставковий дизайн є не тільки активним провідним каналом товарів та послуг на ринок, але й одним із основних видів просування нових технологій, науково-технічних досягнень. Виставка стає місцем спілкування людей, які мають спільні професійні інтереси та мету - залучити до процесу комунікації якнайбільшу аудиторію глядачів та споживачів представлених цінностей. На сучасному етапі виставка здатна значно розширювати інформаційне поле завдяки проведенню у своєму виставковому просторі конференцій, конгресів, конкурсів.

Актуальність теми дослідження. Візуалізація смислових навантажень культури пронизує в суспільстві споживання майже усі види та фрорми людської діяльності, у тому числі і виставкової. Дослідники зазначають, що на певному етапі свого існування люди почали використовувати предмети та оточуюче середовище як інструмент для задоволення інстинктивного імпульсу відкривати, підкреслювати, обожествляти, продавати й інтерпретувати елементи власного досвіду [6]. Таке комунікаційне середовище і було запропоновано розглядати як творчу сферу, яка набувала все більшого визнання, - виставковий дизайн. Цей термін означає передачу інформації через середовище, що оточує людину. Такий підхід створює можливість співпрацювати в якості дизайнерів різних фахівців - архітекторів, працівників музеїв, промислових дизайнерів або істориків, чия спільна робота створює незвичайне поле діяльності. Виставковий дизайн є процесом, що об'єднує різні соери. Звідси, найбільш точним визначенням виставкового дизайну в сучасній літературі вважається наступне: «Виставковий дизайн визначається як інтегративний процес, який у різній мірі поєднує в собі архітектуру, дизайн інтер'єрів, графічний дизайн оточуючого людину середовища, друковану графіку, електронні та цифрові медіа, світло, звук, інтерактивні механізми та інші галузі дизайну» $[6,8]$. У виставковому дизайні важливого значення набуває оточуюче середовище, яке відіграє головну роль у передачі й інтерпретації інформації, залученні аудиторії та посиленні інтенсивності сприйняття і розуміння змісту експозиції. Таким чином, виставковий дизайн виконує комунікативну функцію у житті суспільства, за допомогою особливої мови дає можливість людям пізнати оточуючий світ і самих себе, стає засобом досягнення своїх прагматичних цілей. 3 огляду на те, що останнім часом вплив виставкового дизайну у сфері мистецтва, дизайну і комунікації помітно зріс, вважаємо дослідження даного явища актуальним.

Аналіз останніх досліджень і публікацій. Дослідженню виставкового дизайну як у зарубіжному, так і у вітчизняному мистецтвознавстві приділялася недостатня увага. Деякі автори досліджували ар- 
хітектурно-художнє рішення експозицій музею чи виставки, однак термін «виставковий дизайн» був мало вживаний. У контексті теми слід зазначити праці зарубіжних дослідників щодо визначення концепту виставкового дизайну, з'ясування його місця, ролі, часу зародження та основних тенденцій. Робота американських дизайнерів Я. Лоренца, Л. Сколніка і К. Бергера [6] присвячена історії, актуальним проблемам і процесу сучасного виставкового дизайну.

У вітчизняному полі гуманітарного знання окреслені проблеми теж викликають інтерес широкого кола фрахівців. Зазначимо деякі особливо цікаві підходи Герчанівської П.Е. щодо відображення ментальності та народної культури в художньо-образній системі [3] та Оленіної О.Ю. щодо специфіки мистецтва в сучасному культуркомунікативному просторі [8]. Особливого значення в наш час набувають більш конкретні науково-теоретичні розробки стосовно дизайну предметно-просторового середовища Даниленка В.Я., Бойчука О.В., Свірка В.О., Коваль Л.М., Бондаренка Б.К. та ін., які зробили цінний внесок у розвиток сфери дизайну завдяки дослідженню ролі інноваційних технологій в організації сучасного предметно-просторового середовища. Праця Даниленка В.Я. [4] присвячена розвитку дизайну, дизайнерської професії та освіти, у якій дизайн досліджується у взаємозв'язку з образотворчим мистецтвом, рекламою, архітектурою, кінематографією, музикою тощо. Книга групи авторів «Дизайнерська діяльність: стан і перспективи» [9] презентує досвід провідних країн світу із застосування досягнень дизайну та ергодизайну у підвищенні конкурентоздатності національних економік, який трактується як необхідна передумова розвитку вітчизняного дизайну. Праця Л.М. Коваль з'ясовує принципи формування дизайну предметно-просторового середовища засобами LED-технологій [5].

Слід відзначити роботи сучасних українських дослідників: дисертацію Б.К. Бондаренка «Дизайн предметно-просторового середовища автоцентрів як носіїв ідентичності корпоративних брендів» [1] та дисертаційну роботу Н.С. Брижаченко «Інтерактивність як чинник формування дизайну сучасного громадського інтер'єру» [2], у яких висвітлені окремі питання щодо ролі інноваційних технологій у організації сучасного предметно-просторового середовища. Такий стан розробленості проблеми виставкового дизайну спонукає нас ґрунтовно дослідити виставковий дизайн.

Мета дослідження - з'ясування ролі дизайну виставкових експозицій у сучасній проектнохудожній діяльності.

Виклад основного матеріалу. Історичні зміни в усіх сфрерах життя XXI ст. поставили перед виставковими комплексами нові завдання, спрямовані на залучення сучасного відвідувача. Тому виставкові експозиції відрізняються метою, змістом, часом існування, демонстрацією продукції, фрункціями приміщення, що разом з маркетинговими дослідженнями спрямовані на задоволення потреб споживача. Характерною ознакою експозицій $є$ визначена тема, конкретний зміст, глибоке образне рішення, поглиблена розробка всіх частин експозиції, можливість створення абсолютно нового простору, спирання на текст, артефакти та архівні зображення. На думку вчених, експозиція є «прямою інфрормаційною системою, побудованою за законами мистецтва, працюючою як система мистецтва і дизайну для передачі максимально різноманітної інформації, яку вона здатна фрормувати самостійно притаманними лише їй засобами вираження» $[7,43]$. Якщо експозиції минулих років за характером своїх побудов тяжіли до статичного типу, то останні роки привнесли на виставку динаміку, що виразилася не лише в залученні сучасних технічних засобів, а й у динамізмі авторської інтерпретації експозиційної теми. Головною рисою художнього рішення експозиції стає принцип організації простору за допомогою творчих розробок нових елементів оригінального конструктивного рішення, де відвідувач стає активним учасником експозиції. В основу експозиційного дискурсу втілюється принцип орієнтування на художньо-естетичний вплив на відвідувача, де головну роль відіграє експозиційний образ, який будується на основі наявних предметів-оригіналів з використанням художньо-експозиційних, технічних засобів та новітніх технологій. Створена таким чином експозиція дозволяє передати значиму і ціннісну для суспільства інформацію та виконує культуротворчу місію у сучасному суспільстві. Якщо в експозиції використовуються аудіовізуальні програми, інтерактивні мультимедійні пристрої, то вона стає також засобом встановлення комунікації з молоддю, дітьми, для яких комп'ютерні технології $€$ невід'ємною частиною життя.

Різноманітні підходи у вітчизняній експозиційній творчості та в зарубіжній практиці різняться тенденціями як за цілями, так і за соціально-культурною направленістю. Виставкові експозиції розвинених зарубіжних країн мають досконалу технічну базу, сучасні технології і матеріали, а також достатнє економічне забезпечення і субсидування, що дає можливість прогресивно розвиватися, мати високий рівень дизайнерських розробок, який забезпечує комплексний підхід з естетичними, технічними, фрунціональними властивостями до рішення експозиції.

У вітчизняній експозиційній практиці також велика увага приділена розвитку і реалізації новітніх технологій, впровадженню нових матеріалів та обладнання. Найбільш активно розвивається дизайн експозиційного обладнання та освітлення, активізуються пошуки концептуалізації експозицій, їх більшої інформативності та яскравої видовищності, індивідуальності авторського творчого вирішення.

Сьогоденню притаманна побудова цілісного гармонійного експозиційного ансамблю на основі провідної ролі експоната, в єдності й за участю всіх компонентів експозиції, що в цілому створює емоційно-образне середовише. Експозиції формуються на основі змістовного наукового, концептуального і сценарного контексту з урахуванням специфіки предмета, що експонується, архітектурної ситу- 
ації і реалізації творчих концепцій їх творців. Використовуються як сценографічні принципи побудови експозиційного середовища, так і функціонально-конструктивні підходи сучасного дизайну, що включають архітектурну структуру, інтер'єр, устаткування, мультимедійне обладнання, застосування LEDтехнологій. В експозиційній побудові віддається перевага динаміці показу, емоційності, експресивності і сюжетно-образному розкриттю теми. Вдале поєднання всіх складових виставкового дизайну сприяє його художній виразності, яка залежить від глибокого розуміння дизайнером теми виставки, від уміння втілити цю тему в художньо яскравих, переконливих образах. Ефективність виставкового дизайну забезпечується низкою важливих функцій: просвітницькою, психологічною, естетичною, гедоністичною, комунікативною тощо, які спрямовані на посилення інтересу до виставки та сприйняття речей, найдоступніше забезпечення інфрормацією, отримання задоволення від споглядання предметів експозиції, створення комфортного комунікаційного середовища, привертання уваги глядачів та покупців з метою підвищення споживацького попиту на товар на виставках-продажах.

Виставковий дизайн в сучасному комунікативному просторі набуває ваги завдяки своїй специфрічній мові: нестандартним концептуальним рішенням і розробкам, різноманітним конструкціям, сучасним технічним засобам (формі, кольору, символіці, світлу, рекламі, мультимедійному супроводу) та іншим засобам вираження суті виставки. Як приклад наведемо одну з перших виставок незалежної України бієнале «Пан-Україна'92», що відбулась у Дніпрі (1992 р.) і втілювала важливі ідеї: репрезентувати національну культуру в Україні та за кордоном, продемонструвати рівень національного мистецтва, відтворити славні сторінки української історії, оскільки вона була присвячена 500-літтю Запорізького козацтва. Експозиційний ряд, що включав близько ста робіт майже сорока учасників, відображав стан розвитку національного мистецтва. На бієнале були представлені роботи авторів 3 Києва, Кривого Рога, Миколаєва, Харкова, Сум, Санкт-Петербурга та Детройта. В експозиції були представлені твори малярства, скульптури, графріки, різні за жанрами та творчими методами. Виставка стала свідченням того, що більшість майстрів, творчість яких має національне забарвлення, розробляють нові форми та образи, зосереджуючи увагу на історії та культурі свого народу, прагнучи знайти витоки своєї духовності. Наступна виставка «Пан-Україна» відбулася на День незалежності у 1994 році і набула більш широкого розмаху. Відтоді проведення бієнале стало традицією, що свідчить про участь українського мистецтва у світових процесах.

Виставка робіт народного художника України В.Д. Сидоренка, що демонструвалася в Харкові 3 12 грудня 2012 р. по 20 січня 2013 р., маніфестувала інформацію про сенс свободи у будь-якому суспільстві. Автор запропонував глядачам за допомогою історичної проекції поглянути на сучасність через призму минулого і замислитися над здатністю маніпулювати людьми та їх свідомістю будь-якою системою влади. У художніх творах автора виставки свобода нарешті набуває свого справжнього франтазматичного виміру - простору, де можна позбавитися від кайданів моралі, економічної необхідності, суспільної думки, де можливе лише істинне відображення - правдивий погляд на суть се́бе.

Серед масштабних сучасних виставкових подій важливу роль відіграє київська дослідницька платфрорма PinchukArtCentre. 330 жовтня 2018 р. по 6 січня 2019 р. у центрі проходила виставка «Свій простір», яка запропонувала один із можливих поглядів на історію українського мистецтва та позицію в ньому жінки. Виставка була спрямована на з'ясування позиції жінки-художниці у чоловічому «просторі». Вона презентувала простір як: вимушений/прихований, тілесний/почуттєвий політичний/маніфестаційний. «Простір» конструюється у межах діалогу між творами сучасних митців та історичними творами: агітаційний плакат 1920-30-х років, монументальне мистецтво минулого тощо. Цей простір інфрормує глядача про минуле та сучасність, вчить сказати «ні» негативному і почути голос жінки у суспільстві.

Чільне місце серед великої кількості виставкових заходів займають Міланський тиждень дизайну, Лондонський фрестиваль дизайну, Голландський тиждень дизайну, роблячи вагомий внесок у розвиток предметно-просторового середовища.

Так, участь України у виставці Dutch Design Week в Голландії (м. Ейндховен) 2018 р. свідчить про високий рівень вітчизняного дизайну. Варто відзначити, що українська експозиція вже двічі була представлена на такому важливому «тижні дизайну». Тиждень голландського дизайну - це визначна подія в галузі дизайну та інновацій у Північній Європі, понад триста тисяч фрахівців щороку відвідують цей форум дизайну. Його розглядають як лабораторію майбутнього, що демонструє бачення концептуальних та технологічних інновацій. Назва фрорумy If not us, then who? (Якщо не ми, то хто?) свідчить про важливу роль дизайнера, його намагання створювати відповідальний (екологічний) дизайн, інклюзивний дизайн та технологічний дизайн [10]. За цими трьома дизайнерськими векторами і була створена презентація дизайнерських розробок у стилі «Хороший дизайн для поганого світу», що означає високу міру відповідальності дизайну в творчих рішеннях, спрямованих на екологічність, інклюзивність та технологічність, тобто як буде виглядати наш світ у майбутньому. Одна з виставок під назвою «Чиста революція» мала на меті скоротити використання ресурсів, що не відновлюються, створювати стійкі продукти та мінімізувати кількість відходів. Багато стендів різних країн презентували інклюзивний дизайн, спрямований на забезпечення комфорту для людей з різними фізичними вадами. У цьому напрямку позитивно зарекомендував себе український дизайн, запропонувавши дизайнерські розробки, які відповідали трьом головним вимогам - функціональність, ергономічність, естетичність. 
Український стенд на форумі свідчив про відповідність рівня розробок українських дизайнерів європейським і про те, що створені проекти відповідають сучасним вимогам. Колективний проект Creative Ukraine О. Богданової, О. Оранської, К. Соколової, О. Соломадіної мав на меті показати сучасний український дизайн через посередництво пошуку, експерименту, розвитку. Участь в українській експозиції взяла харківська школа архітектури, яка презентувала оригінальний проект міського простору. Суттєвим здобутком українських дизайнерів стали розробки, призначені для людей з вадами моторики рук і дітей з розладами нервової системи. Змістовну інформацію надали композиції «Колодязь» (А. Хворостьянов), прикраси бренду Tasha Oro з індустріального сміття, розроблені власницею бренду Наталією Єгоровою.

Наукова новизна роботи полягає у системному та ґрунтовному дослідженні концепту «виставковий дизайн», з'ясуванні його ролі і функцій у сучасному суспільстві, яке здійснено вперше.

Висновки. Виставковий дизайн розуміється як сукупність художньо-естетичних і функціональних якостей цілісного предметно-просторового середовища. Він виступає як синтез художньообразної, архітектурної та предметно-просторової організації виставкового середовища з об'єктами експонування та ґрунтується саме на авторському представленні інформативно-змістовної складової експозиції. Мистецтво виставкового дизайну сприяє фрормуванню естетичного предметного середовища, в якому гармонійно поєднуються матеріальні і духовні прагнення людини. Останні два десятиліття привнесли у виставковий дизайн динаміку, яка виразилася у залученні інноваційних технологій - аудіовізуальних та цифрових - та у динамізмі авторської інтерпретації експозиційної теми, що разом створює гармонійне предметне середовище, дозволяє відвідувачам стати учасниками представленої експозиції, посилює емоційний і пізнавальний ефект від ії огляду. Виставковий дизайн сьогодення, спираючись на досягнення науки і техніки, створює новий експозиційний простір, характерними особливостями якого є: художнє проектування виставок на ґрунті даних соціології, психології, кібернетики; використання різних видів мистецтва; зв'язок експоната з життям людини; залежність якості експозиції від розвитку промислового виробництва, яке завжди вимагає раціонального і економічно оправданого використання простору, часу та матеріально-технічних засобів. Під час створення кожного проекту виставки важливо використовувати міждисциплінарний підхід, оскільки роль дизайну полягає у здатності бути інтерпретивним інструментом, що пов'язує людей з їх культурою, історією, технічним прогресом суспільства.

\section{תimepamypa}

1. Бондаренко Б. К. Дизайн предметно-просторового середовища автоцентрів як носіїв ідентичності корпоративних брендів: автореф. дис. на здобуття наук. ступеня канд. мист.: 17.00.07. Харків, 2015. 20 с.

2. Брижаченко Н. С. Інтерактивність як чинник формування дизайну сучасного громадського інтер'єру: автореф. дис. на здобуття наук. ступеня канд. мист.: 17.00.07. Харків, 2016. 20 с.

3. Герчанівська П. Е. Українська народна культура: християнський вимір: монографія. Київ : Університет «Україна», 2011. 426 с.

4. Даниленко В. Дизайн України у світовому контексті художньо-проектної культури : монографрія. Харків : ХДАДМ; Колорит, 2005. 224 с.

5. Коваль Л. М. Принципи формування дизайну предметно-просторового середовища засобами LEDтехнологій: автореф. дис. на здобуття наук. ступеня канд. мист.: 17.00.07. Харків, 2012. 20 с.

6. Лоренц Я., Сколник Л., Бергер К. Дизайн выставок: практическое руководство; пер. с англ. П.В. Кодолова. М. : АСТ: Астрель, 2008. 256 с.

7. Майстровская М.Т. Музейная экспозиция (теория и практика, искусство экспозиции). Москва: Астрель, 1997. 289 c.

8. Оленіна О. Ю. Трансформації мистецтва в комунікативній культурі соціуму: монографія. Харків, 2010. $256 \mathrm{c}$.

9. Свірко В. О., Бойчук О. В., Голобородько В. М., Рубцов А. Л. Дизайнерська діяльність: стан і перспективи. Інформаційно-методичне видання. Київ: УкрНДІ ДЕ, 2014. 171 с.

10. Полисевич Р. Український стенд на Dutch Design Week http://royaldesign.ua/ru/ukranskiy-stend-na-dutchdesign-week.bXvGD/ (дата звернення: 18.03.2019).

\section{References}

1. Bondarenko, B. K. (2015). Design of the object-spatial environment of auto centers as a medium of corporate brand identity. Extended abstract of candidate's thesis. Kharkiv : KhDADM [in Ukrainian].

2. Brigachenko, N. S. (2016). Interactivity as a factor in the design of a modern public interior. Extended abstract of candidate's thesis. Kharkiv : KhDADM [in Ukrainian].

3. Gerchanivska, P. E. (2011). Ukrainian folk culture: Christian dimension: monograph. K. : University "Ukraine" [in Ukrainian].

4. Danilenko, V. (2005). Design of Ukraine in the World Context of Art and Design Culture: monograph. Kharkiv : KhDADM; Color [in Ukrainian].

5. Kova,I L. M. (2012). Principles of the formation of object-space environment design by means of LEDtechnologies. Extended abstract of candidate's thesis. Kharkiv : KhDADM [in Ukrainian].

6. Lorentz, J. \& Skolnik, L. \& Berger, K. (2008). Design of exhibitions: practical guide. (P.V. Kodolov, Trans).

Moscow : AST: Astrel [in Russian]. 
7. Maystrovsky, M. T. (1997). Museum exposition (theory and practice, art of exposition) / M. T. Maystrovsky M. : AST: Astrel [in Russian]. Ukrainian].

8. Olenina, O. Yu. (2010). Transformation of art in the communicative culture of society. Kharkiv : KhDAK [in

9. Svirko, V. O. \& Boychuk, A. V. \& Goloborodko, V. M. \& Rubtsov, A. L. (2014). Designing activity: the state and prospects. Informational and methodical publication K. : UkrNDI DE [in Ukrainian].

10. Polisevich, R. The Ukrainian stand on Dutch Design Week http://royaldesign.ua/ru/ukranskiy-stend-nadutch-design-week.bXvGD/ [in Ukrainian].

Стаття надійшла до редакції 09.12.2019 р. Прийнято до публікації 24.12.2019 p.

UDC 78.078

Tatarnikova Anzhelika

Candidate of Pedagogical Sciences, doctoral candidate, lecturer at the Department of Theoretical and applied Cultural studies of the Odessa National Musical Academy named after A.V. Nezhdanova. ORCID 0000-0002-6310-8276 angelikatatarnikova75@gmail.com

\section{"LIBUSE" by B. SMETANA IN TERMS of CULTURE THE NATIONAL GLORIFICATION}

The purpose of the article is to highlight the positions of the current side of the Opera concept of "Libushe". It is relevant for the modern creative life of Smetana, where the signs of national glorification are concentrated, indicative, as a principle of expression, for the postmodern and post-postmodern cultural space. The methodology of the research is based on art criticism focusing on the culture of glorification. It comes from the cult instructions in the concept of $P$. Florensky, developments in the culture of dithyramb in O. Losev, ideas about the religious and cult principles of positive ritual in E. Durkheim. Art criticism in the development of cult installations of B. Asafiev's research considers the principles of consideration of the composition "Libushe" by B. Smetana and defines analytical, historical-descriptive, comparativestylistic, interdisciplinary-comparative methods. The scientific novelty of the work is as follows: for the first time in the domestic cultural studies and artistic developments focused attention on the cultural phenomenon of worship as part of the expression of the national idea of the composition of the musical-a stage performance called Opera. Conclusions. Generalization of the spiritual-semantic and dramaturgical specifics of "Libushe" Would. B. Smetana allows us to put forward the concept of quasi-liturgical content of the named work. This poetics reveals creative and ideological parallels to the stage performance of "Ruslan and Lyudmila" by M. Glinka as the "Slavic Liturgy". According to B. Asaf'ev, both before Wagner's musical and theatrical heritage and its mythopoetic attitudes and before the Pasion of J. S. Bach-piest, he realized that Lutheranism was in contact with the Byzantine liturgical practice.

Key words: "Libushe" by B. Smetana, cult, culture, national glorification, liturgical foundations of the composition structure, pietism by Y.S. Bach.

Татарнікова Анжеліка Анатоліївна, кандидат педагогічних наук, докторант, викладач кафредри теоретичної та прикладної культурології Одеської національної музичної академії ім. А. В. Нежданової

«Лібуше» Б. Сметани у вираженні культури національного славлення

Метою даної роботи є висвітлення позицій актуальної для сучасного творчого буття сторони оперної концепції «Лібуше» Б. Сметани, в якій зосереджені ознаки національного славлення, показові, як принцип вираження, для постмодернового і пост-постмодернового культурного простору. Методологічною основою дослідження покладено мистецтвознавчі зосередження на культурі уславлення, що походять з культових настанов в концепції П. Флоренського, розробок з культури дифірамбу у О. Лосєва, уявлень про релігійно-культові засади позитивного ритуалу у Е. Дюркгейма, а також мистецтвознавче спрямування у розробках культових установлень в дослідженнях Б. Асаф'єва. Відповідно, аналітичний, історико-описовий, компаративно-стильовий, міждисциплінарно-порівняльний методи визначають принципи розгляду композиції «Лібуше» Б. Сметани. Наукова новизна роботи полягає у наступному: вперше у вітчизняному культурознавстві і мистецтвознавчих розробках зосереджена увага на культурному феномені славлення як складової вираження національної ідеї у композиційному рішенні музично-сценічної дії названої опери. Висновки. Узагальнення духовно-смислової та драматургічної специфіки «Лібуше» Б. Сметани дозволяє висунути концепцію quasi-літургійного наповнення названого твору, поетика якого виявляє творчо-ідеологічні паралелі і до сценічного дійства «Руслана і Людмили» М. Глинки як «слов'янської літургії» за Б. Асаф'євим, і до вагнерівського музично-театрального спадку та його міфопоетичних настанов, і до пасіону Й. С. Баха-пієтиста, що усвідомлював контактність лютеранства з візантійською літургійною практикою.

Ключові слова: «Лібуше» Б. Сметани, культ, культура, національне славлення, літургійні засади будови композиції, пієтизм Й. С. Баха.

(c) Tatarnikova A., 2020 